\title{
TACIT KNOWLEDGE AND FIRM PERFORMANCE RELATIONSHIP. THE ROLE OF PRODUCT INNOVATION AND THE FIRM LEVEL CAPABILITIES
}

\author{
M. Ángeles LÓPEZ-CABARCOS ${ }^{1 *}$, Suresh SRINIVASAN ${ }^{2}$, \\ Sérgio GÖTTLING-OLIVEIRA-MONTEIRO ${ }^{3}$, Paula VÁZQUEZ-RODRÍGUEZ ${ }^{4}$ \\ 1, ${ }^{4}$ Department of Business Administration, Facultad de Administración y Dirección de Empresas, \\ University of Santiago de Compostela, Lugo, Spain \\ ${ }^{2}$ Great Lakes Institute of Management, Chennai, India \\ ${ }^{3}$ Department of Business Administration, Instituto Superior de Contabilidad e Administração, \\ Porto, Portugal
}

Received 12 July 2018; accepted 11 February 2019

\begin{abstract}
Based on knowledge-based theory of organizational capabilities and dynamic capabilities theory, this paper tries to establish the linkages between tacit knowledge resources, its integration into firm level capabilities, product innovation and firm performance. In this way, the paper analyses the relationships between some of the most relevant variables to the organizations in order to remain competitive. The conceptual model is tested using a sample of organizations in the industrial sector, using SEM and hierarchical regression analysis. Results show a positive relationship between tacit knowledge and firm performance, tacit knowledge and product innovation, and product innovation and firm performance. A partial mediating effect of product innovation on the tacit knowledge firm performance relationship is established. Also, technical capabilities have a moderator effect on tacit knowledge firm performance relationship. At the end of the paper managerial implications are commented, as well directions for future studies.
\end{abstract}

Keywords: firm performance, product innovation, tacit knowledge, organizational capabilities, marketing capabilities, technical capabilities.

JEL Classification: M10, M11.

\section{Introduction}

Knowledge is becoming increasingly a strategic resource impacting firm performance and hence has become the focus of both research and practice (Heffner \& Sharif, 2008). Tacit knowledge is a source of competitive advantage due to is inimitability, being along with the firm level capabilities imperatives for product innovation (Grant, 1996a), this is the ability of firms to consistently deliver new products and services that addresses customer's precise

${ }^{\star}$ Corresponding author. E-mail: angeles.lopez.cabarcos@usc.es 
needs ahead of the competition (Fernandes, Ferreira, \& Raposo, 2013).

Prior research on the relationship between knowledge and innovation showed that such relationship would be strong with superior organizational capabilities (Leal-Rodríguez, LealMillán, Roldán-Salgueiro, \& Ortega-Gutiérrez, 2012) like knowledge sharing and integration, but firm performance was not integrated into the model. Several studies also highlighted the importance of tacit knowledge sharing in new product development (Goffin \& Koners, 2011), but firm performance and capabilities were not considered. Other studies that explored impact of innovation on firm performance showed a positive relationship, but their framework did not include tacit knowledge and firm level capabilities (Fernandes et al., 2013). Recent studies have also explored the impact of explicit and tacit knowledge sharing on firm performance and also tested the mediating role of innovation, but firm level capabilities had not been considered in the model (Z. Wang \& N. Wang, 2012). Prior studies also examined the impact of tacit market knowledge and its moderation effects with organizational capabilities on firm performance, but product innovation was not integrated into the model (De Luca \& Atuahene-Gima, 2007). Krasnikov and Jayachandran (2008) explored the impact of capabilities on firm performance, more specifically which capability, i.e., marketing, research and development or operations had a stronger impact on firm performance. Although their study had accounted for the differential intensity of tacit knowledge between the three chosen capabilities, product innovation was not included in their framework. From the review of past and recent literature, it is clear that there is not a comprehensive model that links tacit knowledge, product innovation, firm level capabilities (organizational, marketing and technical capabilities) and firm performance. Over the past three decades scholars have considered knowledge as one of the most important and necessary resources for successful organizations (Barley, Treem, \& Kuhn, 2018), however more research is needed to understand the contribution of knowledge management, especially of knowledge sharing, innovation performance and competitive advantage (Heisig et al., 2016).

It is well documented that tacit knowledge translates into superior firm performance, being the main interest of the paper to know how this process is carried out. That is, does tacit knowledge directly impact firm performance or is the superior firm performance achieved through product innovation? This study attempts to present a comprehensive model that combines and integrates a wide array of tacit knowledge available within the firm through firm specific capabilities (organizational, marketing or technological) to achieve competitive advantages for organizations in terms of new products and firm performance. The conceptual model developed and tested in this study draws upon and furthers knowledge-based theory of organizational capabilities (Grant, 1996a, 1996b) and the theory of dynamic capabilities (Teece, 2007; Teece, Pisano, \& Shuen, 1997). To this end, this paper analyses survey data collected from 153 medium and large organizations in the industrial sector.

The layout of this article is as follows. Section 1 offers a conceptual framework in which the mediation and moderation hypotheses are based. Section 2 provides an explanation of the method and the procedure followed in this study. Results are presented is Section 3. Section 4 describes and discusses the findings. Section 5 explains the managerial implications of the study. The final section presents the conclusions, limitations of the study and future research avenues. 


\section{Conceptual framework and hypothesis}

Polanyi (1962) classified knowledge into tacit and explicit, describing tacit knowledge as something that cannot be expressed accurately and codified, but reflected in abilities and skills, insights and experiences; while explicit knowledge can be codified, documented, stored and retrieved within organizations. Hence, from a strategic perspective explicit knowledge, being public in nature (Seidler-de Alwis \& Hartmann, 2008), is not a source of competitive advantage (Grant, 1996b). Contrarily, tacit knowledge, which cannot be codified, readily tradable and its transfer between people is characterized by slowness, uncertainty and high cost (Kogut \& Zander, 1992), is a key source of competitive advantage. Since organizations are moving away from "tangible asset" intensive environments to "intellectual and tacit knowledge" intensive environments, the role of managers to successfully integrate knowledge has become more demanding (Thall, 2005). The question is how tacit knowledge is manifested in organizations. Market tacit knowledge is acquired by virtue of staying close to customers and resides as experiences and perceptions based on the understanding of customer problems (Polanyi, 1962). Managerial depth and insights, which are predominantly tacit in nature, lie at the centre of integrating diverse tacit knowledge into inimitable organizational capabilities (Regner \& Zander, 2011). And tacit technological knowledge is the ability to obtain skills to design, build, equip and use new facilities for automation and improve efficiency of current operations for introducing new products (Flor \& Oltra, 2005).

\subsection{Direct relationships and mediating effect}

The fundamental question in the field of strategic management is rooted in explaining firm performance (Grant, 1996b) and how firms sustain competitive advantage (Teece et al., 1997). While RBV has been criticized for its inability to explain how resources are developed and deployed to sustain competitive advantage (Morgan, Vorhies, \& Mason, 2009); the theory of dynamic capabilities enables firms to create deploy and protect intangible assets that support superior long run performance (Teece, 2007). It is the ability of the firm "to sense and shape opportunities and threats, to seize opportunities and to maintain competitiveness through enhancing, combining, protecting and, when necessary, reconfiguring the firm's intangible and tangible assets" (Teece, 2007, p. 1).

In this context, product innovation can be understood as introducing new products to be ahead of the competition, which also includes resources allocated by the company towards R\&D initiatives focused towards new product development and the "processes" leading up to new product development. Thus, it is also necessary to capture the underlying processes, actions or strategies that firms use to achieve improved innovation performance (Jayaram, Oke, \& Prajogo, 2014). The objective is to capture also the processes that cover product conceptualization to market launch, which have a bearing on the firm's new product development capability by impacting the cycle time and depend on the effectiveness of cross-functional, multi-disciplinary teams (Terziovski, Sohal, \& Howell, 2002). So, product innovation capability becomes crucial and it is achieved through combining complementary innovation (Teece, 2007) and creating capabilities that not only meet the current demands of the customers, but also their future desires ahead of the competition (Ruvio, Shoham, Vigoda-Gadot, \& Schwab- 
sky, 2014). Prior research has used innovation in the contexts of new product development (Goffin \& Koners, 2011), customer intimacy and responding to market needs (Morgan et al., 2009), new market insights that meet customer needs (Fernandes et al., 2013), the novelty of an idea (Seidler-de Alwis \& Hartmann, 2008), and the ability to penetrate new markets (Cavusgil, Calantone, \& Zhao, 2003). New products require new combination of already existing knowledge generated through acquisition, assimilation and dissemination of new knowledge (Cohen \& Levinthal, 1990). Product innovation and competitive advantage are a result of superior tacit knowledge management (Grant, 1996a), resulting in innovative products (Li \& Calantone, 1998). Tacit knowledge in the form of well-developed market has a positive relationship with product innovation (Atuahene-Gima, Slater, \& Olson, 2005). Hence, the following hypothesis is proposed: H1: Tacit knowledge has a positive impact on product innovation.

R\&D expenditure and innovation capacity in terms of innovation in products, processes or patent numbers is important for progress, competitiveness and economic development (Gallego-Álvarez, Prado-Lorenzo, \& García-Sánchez, 2011) and has a positive impact on firm performance (Fernandes et al., 2013). Innovation in terms of new products is vital for business growth (Cucculelli \& Ermini, 2012), especially in the context of an intense global competition and a rapid increase in the pace of technological development (Seidler-de Alwis \& Hartmann, 2008). Pittiglio and Reganati (2015) argue that product and process innovation are important capabilities for firm's survival, especially in technology intensive sectors. Ability to innovate is a competitive advantage that emanates from idiosyncratic combinations of tacit knowledge, resulting in superior firm performance (Teece, 2007). Innovative companies record better productivity and firm size (Lentz \& Mortensen, 2005), financial performance (Cucculelli \& Ermini, 2012), or better contribution to customer needs (Z. Wang \& N. Wang, 2012). Hence, this hypothesis is proposed: H2: Product innovation has a positive impact on firm performance.

It seems clear that tacit knowledge plays a strategic role in organizational success (Chen \& Mohamed, 2010; Nonaka \& Takeuchi, 1995). However, some authors suggest that tacit knowledge does not necessarily impact front line workers' productivity which is a key element of firm performance (Paladino, Hargiss, \& Howard, 2016) and some authors state that not all knowledge positively impact firm performance, only higher value knowledge (Fallatah, 2018). Anyway, it is also true that tacit knowledge can improve innovation, creativity potential and overall competitive position of the firm (Zeng \& Tang, 2014); since organizations are moving away and being inimitable, tacit knowledge provides the firm a superior competitive advantage (Teece, 2007). An organization's ability to read marketplace changes (like customer pain points and competitor reactions) and internalize such tacit knowledge within the firm for decision making and superior capability building, results in competitive advantage (Arnett \& Wittmann, 2014). Therefore, the following hypothesis proposed is: H3: Tacit knowledge has a positive impact on firm performance.

So, tacit knowledge is expected to impact firm performance directly or through product innovation. In this sense, Al-Hakim and Hassan (2016) state that knowledge management implementation has a positive impact on organizational performance through partial mediating effect of innovation. Hence, this study also intends to study the role of product innovation in tacit knowledge firm performance relationship. 


\subsection{Moderation effects}

Knowledge based theory of organizational capabilities (Grant, 1996a) advocates that knowledge is a source of competitive advantage only if the firm establishes an effective linkage between knowledge inputs and product outputs (Brown \& Duguid, 1998; Grant, 1996b). The primary role of the firm is to integrate individual specialist knowledge into organizational routines and capabilities. Employee's potential knowledge and the organizational environment are important components of a firm's knowledge capability (Bivainis \& Morkvènas, 2012). Under conditions of dynamic competition, reconfiguring and extending existing capabilities to encompass new knowledge and achieving flexible integration, result in superior products and sustainable competitive advantage (Kogut \& Zander, 1992). The organizational structure stimulates the development of knowledge search routines and the capability of the managers in integrating such knowledge within the firm (Tippmann, Sharkey, \& Mangematin, 2014). Both, knowledge-based theory and dynamic capabilities theory focus on organizational structure (Grant, 1996b; Lubit, 2001), coordination and integration mechanisms, which are nothing, but organizational capabilities. Managerial depth and insights facilitate such knowledge integration. While top managers play an anchoring role in integrating tacit knowledge within firms, middle managers play an even more critical role in creating organizational capabilities by serving as the bridge (Nonaka \& Takeuchi, 1995) between top and first line managers (Thall, 2005). Possessing dynamic capabilities per se will not lead to superior organizational performance; firms need to align their internal organizational structure to sense and seize external opportunities and reconfigure their resource base accordingly (Wilden, Gudergan, Nielsen, \& Lings, 2013). The organization can be understood as the central actor in knowledge creation, by recombining existing knowledge to create new knowledge and combining knowledge created by individual members in a value adding way (Iyer, Sharp, \& Brush, 2017). Tacit knowledge and knowledge sharing in the nature of cooperation and constructive participation interact in explaining knowledge effectiveness (Wu \& Lin, 2013). Collaboration and working in pairs favourably impact task complexity and performance effectiveness relationship (Balijepally, Mahapatra, Nerur, \& Price, 2009). While vertically imposed structures restrict cooperation between specialists that can harvest tacit knowledge (Grant, 1996a), cross functional structures and strategic planning crystallizes those ideas into the firm's organizational intelligence (Nonaka, 1994), which has a potential to improve firm performance (M. Song, Im, Bij, \& L. Z. Song, 2011).

Impact of tacit knowledge on innovation and competitiveness is enhanced through providing incentives for a team-based culture within the firm (Grant, 1996b). A moderating role of tacit knowledge and knowledge integration mechanisms in explaining innovation outcomes is documented (Leal-Rodriguez et al., 2012). Organizational capabilities in terms of nature of firm climate play an important role in transforming knowledge into innovation (Seidler-de Alwis \& Hartman, 2008). Fusing knowledge-based theory of capabilities and dynamic capabilities theory; it is evident that organizational capabilities in terms of knowledge integration play an important role in achieving firm performance. Therefore, these hypotheses are proposed: $\mathrm{H}_{4}$ : Organizational capabilities moderate the relationship between tacit knowledge and product innovation; $\mathrm{H}_{5}$ : Organizational capabilities moderate the relationship between tacit knowledge and firm performance. 
Marketing capabilities are usually associated with individual marketing mix processes (Vorhies \& Morgan, 2005). The effectiveness of tacit marketing knowledge focused on meeting customer requirements through tailor made innovative products is enhanced by the marketing capabilities that share and integrate such knowledge within the firm, resulting in focused marketing programs different from traditional marketing practices adopted by the competitors (Arnett \& Wittmann, 2014). In this sense, knowledge that flows from customers or even suppliers can be determinant for successful innovation (Wadho \& Chaudhry, 2018). A firm's ability to innovate in terms of new products depends not only on its existing competencies, but its ability to renew knowledge relating to unmet customer needs (Danneels, 2002). A firm's ability to leverage knowledge about current and future customers and the market intelligence associated with superior team performance depends on the extent of the firm's marketing capabilities or the deployment mechanisms (Madhavan \& Grover, 1998). Morgan et al. (2009) state that a firm's marketing capabilities moderate its market knowledge firm performance relationship. Hence, these hypotheses are proposed: $\mathrm{H}_{6}:$ Marketing capabilities moderate the relationship between tacit knowledge and product innovation; $\mathrm{H}_{7}$ : Marketing capabilities moderate the relationship between tacit knowledge and firm performance.

Technical capabilities manifest in the form of tangible assets, like plant and equipment; intangible assets, like skills to handle product and process technologies, patents, licenses, and R\&D capability (Howells, 1996; Seidler-de Alwis \& Hartman, 2008); and the presence of scale and scope economies (Macher \& Boerner, 2006). Technology plays a dominant role in the use of tacit knowledge in firm innovation capabilities (Flor \& Oltra, 2005; Howells, 1996). Recent studies point out that product innovation helps firms to renew their technical capabilities through acquisition of new knowledge (Wang \& Chen, 2018). Information technology systems record rich information about the past and ongoing projects and provide a platform for not only sharing explicit knowledge (Chen \& Mohamed, 2010), but also to

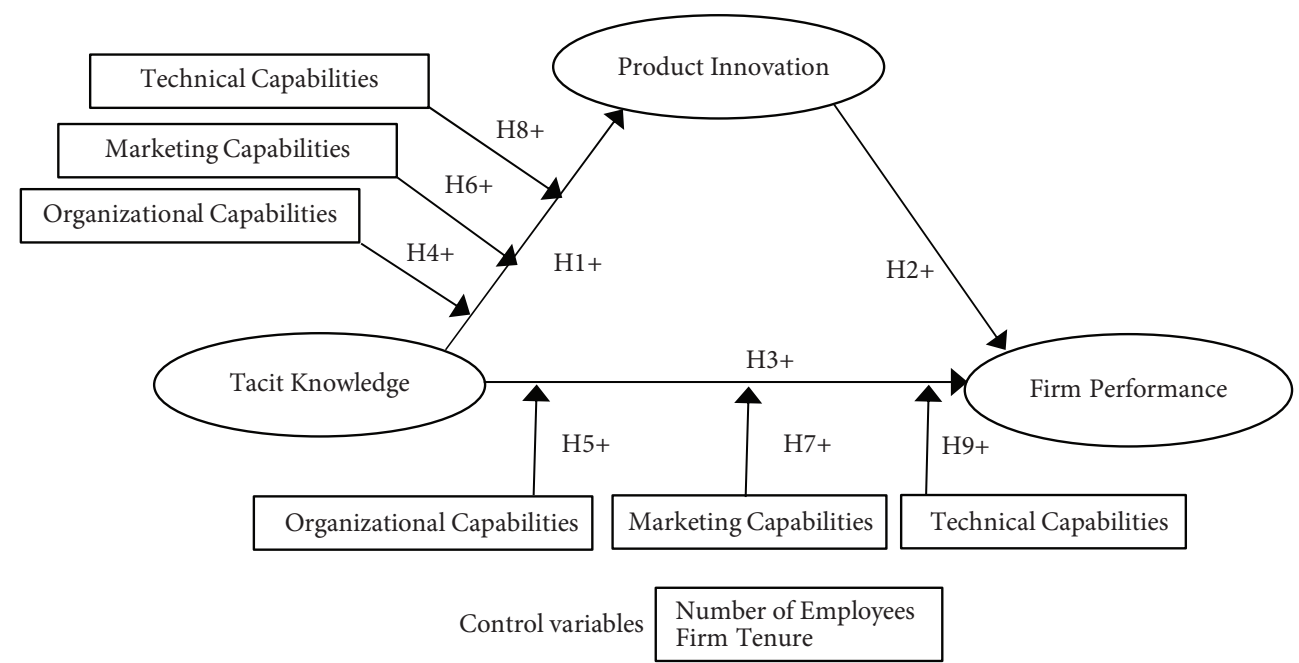

Note: Paths were added from the control variable to the endogenous variables.

Figure 1. Proposed model 
fuse collaborative knowledge creating capabilities and thereby turn an organization into a "knowledge creating company" (Nonaka, Umemoto, \& Senoo, 1996). Technical capabilities impact the ability of firms to leverage learning from collaboration into superior performance (Flor \& Oltra, 2005). These capabilities interact with tacit knowledge of the customers and market knowledge in impacting firm performance ( $\mathrm{Su}$, Peng, Shen, \& Xiao, 2013). Leonard and Sensiper (1998) argue that information technology can be only of limited help in transferring tacit knowledge to superior firm performance. However, Kabir and Carayannis (2013) show that with advancements in information technologies, more types of tacit knowledge can be made transferable and accessible to employees across the organization, providing the firm a competitive advantage. Hence, these hypotheses are proposed: $\mathrm{H}_{8}$ : Technical capabilities moderate the relationship between tacit knowledge and product innovation; $\mathrm{H}_{9}$ : Technical capabilities moderate the relationship between tacit knowledge and firm performance.

Figure 1 summarizes all the hypotheses.

\section{Methodology}

\subsection{Participants and procedure}

The population of this study included 521 industrial organizations with more than 50 employees. Data were obtained from the Portuguese National Institute of Statistics. At the end of the data collection process, responses had been obtained from 153 organizations, or 29\% of the study universe, which is in line with similar research in the field (T. Cater \& B. Cater, 2009; Rivard, Raymond, \& Verreault, 2005). 64.5\% are private limited companies and $33.6 \%$ are public limited companies. 57\% of the firms present less than 100 employees, 39\% have between 100 and 249 employees, and $4 \%$ had more than 249 employees. The medium age of the firms is about 20 years $(S D=13.74)$.

The methodology comprised of sending a questionnaire to all the organizations' managers accompanied by a letter of instructions and a declaration of confidentiality in data processing. Structural equation modelling (SEM) and hierarchical multiple regression were used to test the hypotheses, using a SPSS 22.0 AMOS package.

\subsection{Instruments}

The scale of tacit knowledge used was proposed by Choi and Lee (2003) and supported by other authors (Choi \& Jong, 2010; Leite, 2004). Four items were included based on a 5-point Likert scale (1, totally disagree; 5 , totally agree). Scales for product innovation, firm performance and firm capabilities used were taken from Spanos and Lioukas (2001). The scale for product innovation was supported by Pertusa-Ortega, Molina-Azorín, and Claver-Cortés (2009). Four items were included based on a 5-point Likert scale (1, weaker than competitors; 5 , stronger than competitors). Performance's perception was measured in a dimension named as firm performance (four items) (Choi \& Lee, 2003). A 5-point Likert scale was used (1, far below average: 5 , far above average). The respondents were asked to rate the items in relative terms to competitors, considering over a three-year period (Arend, 2006). Scales for organizational capabilities, marketing capabilities and technical capabilities were also supported by 
other authors (Rivard et al., 2005). Fourteen items were considered based on 5-point Likert scale (1, far below average; 5 , far above average). Finally, number of employees and firm tenure (years) were included as control variables.

\section{Results}

\subsection{Common method bias}

Data was collected from a single sitting and a self-reporting measure, potentially resulting in a common method variance that it was controlled using recommendations made by Podsakoff, MacKenzie, Lee, and Podsakoff (2003). Respondents were asked to provide honest answers and were guaranteed that their responses would be anonymous; the independent variables were located before the dependent ones; and tested and confirmed scales were used. Additionally, Harman's single factor test (Harman, 1967) was used to model all of the items as indicators of a single factor that represents method effects. The analysis revealed the existence of three factors (eigenvalues $>1$ ), which explained $78.20 \%$ of the total variance, explaining the first factor less than the $50 \%$ of the total variance. Furthermore, all the variables were loaded onto one factor in order to examine the fit of the confirmatory factor analysis (CFA) model (Korsgaard \& Roberson, 1995). The results concluded that the single-factor model did not fit data well and significantly worse than the measurement model. So, most of the variance in this data was explained by the individual constructs and common method variance did not seem to be a significant problem in this study (Podsakoff et al., 2003).

\subsection{Measurement model}

Descriptive statistics, Cronbach's alpha and simple correlations among the variables used in this study are presented in Table 1 . The number of employees was significantly correlated to all the variables of the model. Firm tenure was correlated to product innovation, firm performance and capabilities, so they were controlled to test the model (Shi, Chen, \& Zhou, 2011). All the rest of the variables used in the model were positively correlated to the others.

Table 1. Descriptive statistics, Cronbach's alpha and correlations among study variables

\begin{tabular}{|c|c|c|c|c|c|c|c|c|c|c|}
\hline & M & SD & NE & FT & TK & PI & FP & OC & MC & TC \\
\hline $\mathrm{NE}$ & 108.03 & 82.49 & - & & & & & & & \\
\hline FT & 22.92 & 15.54 & $0.334^{(* *)}$ & - & & & & & & \\
\hline TK & 3.26 & 0.94 & $0.226^{(* *)}$ & 0.155 & 0.903 & & & & & \\
\hline PI & 2.94 & 0.95 & $0.319^{(* *)}$ & $0.181^{(*)}$ & $0.651^{(* *)}$ & 0.907 & & & & \\
\hline $\mathrm{FP}$ & 3.13 & 0.90 & $0.241^{(* *)}$ & $0.170^{(*)}$ & $0.664^{(* *)}$ & $0.690^{(* *)}$ & 0.904 & & & \\
\hline $\mathrm{OC}$ & 3.23 & 0.82 & $0.231^{(* *)}$ & $0.238^{(* *)}$ & $0.738^{(* *)}$ & $0.666^{(* *)}$ & $0.732^{(* *)}$ & 0.930 & & \\
\hline MC & 3.11 & 0.89 & $0.317^{(* *)}$ & $0.262^{(* *)}$ & $0.673^{(* *)}$ & $0.603^{(* *)}$ & $0.743^{(* *)}$ & $0.805^{(* *)}$ & 0.899 & \\
\hline TC & 3.42 & 0.79 & $0.269^{(* *)}$ & $0.170^{(*)}$ & $0.430^{(* *)}$ & $0.457^{(*)}$ & $0.599^{(*)}$ & $0.662^{(* *)}$ & $0.589^{(*)}$ & 0.845 \\
\hline
\end{tabular}

Note: $\mathrm{N}=153$. Variables: Number of employees (NE); Firm tenure (FT); Tacit knowledge (TK); Product innovation (PI); Firm performance (FP); Organizational capabilities (OC); Marketing capabilities (MC); Technical capabilities (TC). Cronbach's $\alpha$ on the diagonal. ${ }^{*} p<0.05 ;{ }^{* *} p<0.01$. 
Table 2 presents the standardized measurement coefficients, the composite reliability $(>0.7)$ and the average variance extracted (AVE $>0.5)$ (Fornell \& Larcker, 1981). Convergent and discriminant validity were confirmed following the recommendations of Hair, Black, Babin, and Anderson (2010), so the scale's reliability was considered to be confirmed. The goodness-of-fit indices of the model presented good values; $\chi^{2}(d f)=483,092(283), p<$ $0.001, \mathrm{GFI}=0.811, \mathrm{RMSEA}=0.068, \mathrm{TLI}=0.931, \mathrm{CFI}=0.940, \chi^{2} / d f=1.707$.

Table 2. Standardized measurement coefficients, composite reliability and AVE

\begin{tabular}{|c|c|c|c|c|}
\hline Latent variable & Indicator & $\begin{array}{l}\text { Standardized } \\
\text { weights }\end{array}$ & $\begin{array}{l}\text { Composite } \\
\text { reliability }\end{array}$ & AVE \\
\hline $\begin{array}{l}\text { Tacit } \\
\text { knowledge }\end{array}$ & $\begin{array}{l}\text { Employees' knowledge can contribute to } \\
\text { be used by specialists or pairs of work } \\
\text { It is easy for employees to acquire } \\
\text { knowledge through direct contact with } \\
\text { experts or pairs of work } \\
\text { Informal conversations or meetings are } \\
\text { used to share knowledge } \\
\text { Knowledge can be acquired through } \\
\text { designated mentors for this purpose }\end{array}$ & $\begin{array}{l}0.708^{* * *} \\
0.831^{* * *} \\
0.886^{* * *} \\
0.882^{* * *}\end{array}$ & 0.898 & 0.689 \\
\hline $\begin{array}{l}\text { Product } \\
\text { innovation }\end{array}$ & $\begin{array}{l}\text { Differentiation R\&D expenditures for } \\
\text { product development } \\
\text { R\&D expenditures for process innovations } \\
\text { Emphasis on being ahead of competition } \\
\text { Rate of product innovations }\end{array}$ & $\begin{array}{l}0.799^{\star * *} \\
0.815^{\star * *} \\
0.848^{\star * *} \\
0.861^{\star * *}\end{array}$ & 0.899 & 0.691 \\
\hline $\begin{array}{l}\text { Firm } \\
\text { performance }\end{array}$ & $\begin{array}{l}\text { Turnover } \\
\text { Sales growth } \\
\text { Market share } \\
\text { Market share growth }\end{array}$ & $\begin{array}{l}0.733^{\star * \star} \\
0.869^{\star * \star} \\
0.812^{\star * *} \\
0.936^{\star * \star}\end{array}$ & 0.905 & 0.707 \\
\hline $\begin{array}{l}\text { Organizational } \\
\text { capabilities }\end{array}$ & $\begin{array}{l}\text { Ability to attract creative employees } \\
\text { Strategic planning } \\
\text { Coordination } \\
\text { Efficient organizational structure } \\
\text { Firm climate } \\
\text { Knowledge and skills of employees } \\
\text { Managerial competencies }\end{array}$ & $\begin{array}{l}0.764^{\star \star \star} \\
0.802^{\star \star \star} \\
0.852^{\star \star \star} \\
0.837^{\star \star \star} \\
0.805^{\star \star \star} \\
0.813^{\star \star \star} \\
0.813^{\star \star \star}\end{array}$ & 0.932 & 0.660 \\
\hline $\begin{array}{l}\text { Marketing } \\
\text { capabilities }\end{array}$ & $\begin{array}{l}\text { Customers "installed base" } \\
\text { Advantageous relationships with } \\
\text { costumers } \\
\text { Control and access to distribution } \\
\text { channels } \\
\text { Market knowledge }\end{array}$ & $\begin{array}{l}0.867^{* * *} \\
0.820^{\star * *} \\
0.810^{\star * *} \\
0.834^{* * *}\end{array}$ & 0.901 & 0.694 \\
\hline $\begin{array}{l}\text { Technical } \\
\text { capabilities }\end{array}$ & $\begin{array}{l}\text { Efficient and effective production } \\
\text { department } \\
\text { Economies of scales and technical } \\
\text { experience } \\
\text { Technological capabilities and equipment }\end{array}$ & $\begin{array}{l}0.783^{\star * *} \\
0.840^{\star * *} \\
0.803^{\star * *}\end{array}$ & 0.850 & 0.654 \\
\hline
\end{tabular}




\subsection{Structural model}

The results show that the theoretical model fit was good; $\chi^{2}(d f)=89,703(69), p<0.001$, $\mathrm{GFI}=0.923, \mathrm{RMSEA}=0.0044, \mathrm{TLI}=0.981, \mathrm{CFI}=0.986, \chi^{2} / d f=1.3$. The number of employees was significantly related to product innovation, unlike the firm tenure which was not related with any other variable. The structural paths between tacit knowledge and product innovation $(\beta=0.683, p<0.001)$, product innovation and firm performance $(\beta=0.478, p<$ $0.001)$, and tacit knowledge and firm performance $(\beta=0.393, p<0.001)$, were significant, thus confirming $\mathrm{H}_{1}, \mathrm{H}_{2}$ and $\mathrm{H}_{3}$. The results indicate that tacit knowledge accounts for $52.2 \%$ of the product innovation, and tacit knowledge and product innovation account for $65.3 \%$ of firm performance.

Results also show that product innovation partially mediates the tacit knowledge firm performance relationship. In order to fully confirm this result, two additional models were tested. As shown in Table 3, the relationship between tacit knowledge and firm performance is significant in Model 3 (direct effects), and it does not disappear once product innovation is taken into consideration (Model 1). The paths from tacit knowledge to product innovation and from product innovation to firm performance remain significant in partial and full mediation models. Sobel test (1982) also supports the mediating effect of product innovation $(z=10.47 ; p<0.001)$. As shown in Table 3 , the $\chi^{2}$ of partial mediation model (1) was lower than the $\chi^{2}$ of full mediation model (2) and direct relation model (3), and significantly different $\left(\Delta \chi^{2}=14.116, \Delta d f=1\right)\left(\Delta \chi^{2}=1115.756, \Delta d f=2\right)$, respectively.

Results show VAF of 0.463 and support also partial mediation as it falls within the range of 0.20 to 0.80 (Hair, Hult, Ringle, \& Sarstedt, 2014). So, the above results support the acceptance of Model 1 as a better choice. Thereby, the results show that product innovation partially mediates the tacit knowledge firm performance relationship.

Table 3. Fit results and path coefficients for structural equation models

\begin{tabular}{|c|c|c|c|c|c|c|c|}
\hline & $\chi^{2}(d f)$ & $\mathrm{p}$ & GFI & RMSEA & TLI & CFI & $\chi^{2} / d f$ \\
\hline $\begin{array}{l}\text { Model } 1 \text { (par- } \\
\text { tial mediation) }\end{array}$ & $70.301(49)$ & 0.000 & 0.928 & 0.053 & 0.980 & 0.985 & 1.435 \\
\hline $\begin{array}{l}\text { Model } 2 \text { (full } \\
\text { mediation) }\end{array}$ & $84.417(50)$ & 0.000 & 0.915 & 0.067 & 0.968 & 0.976 & 1.688 \\
\hline \multirow[t]{3}{*}{$\begin{array}{l}\text { Model } 3 \text { (direct } \\
\text { effects) }\end{array}$} & $186.057(51)$ & 0.000 & 0.859 & 0.132 & 0.878 & 0.906 & 3.648 \\
\hline & \multicolumn{7}{|c|}{ Standardized coefficients and ( $t$-values) } \\
\hline & \multicolumn{3}{|c|}{$\begin{array}{l}\text { Tacit knowledge } \rightarrow \\
\text { Product innovation }\end{array}$} & \multicolumn{2}{|c|}{$\begin{array}{l}\text { Product innovation } \\
\rightarrow \text { Firm performance }\end{array}$} & \multicolumn{2}{|c|}{$\begin{array}{l}\text { Tacit knowledge } \rightarrow \\
\text { Firm performance }\end{array}$} \\
\hline Model 1 & \multicolumn{3}{|c|}{$0.713(13.20)^{\star \star \star}$} & \multicolumn{2}{|c|}{$0.475(4.32)^{\star * *}$} & \multicolumn{2}{|c|}{$0.392(3.47)^{\star * *}$} \\
\hline Model 2 & \multicolumn{3}{|c|}{$0.752(14.46)^{* * *}$} & \multicolumn{2}{|c|}{$0.791(15.19)^{\star * *}$} & & \\
\hline Model 3 & & & & & & \multicolumn{2}{|c|}{$0.728(12.13)^{* * *}$} \\
\hline
\end{tabular}

${ }^{* * *} p<0.001$. 


\subsection{Moderating effects}

Moderating effects of tacit knowledge and firm capability dimensions on product innovation, and tacit knowledge and firm capability dimensions on firm performance were examined using hierarchical multiple regression (J. Cohen \& P. Cohen, 1983). Specifically, organizational capabilities, marketing capabilities and technical capabilities were used as separate moderators in both relationships. Estimated reliability of the moderator variables was calculated; in all the cases, acceptable values exceed 0.8 (Bagozzi \& Yi, 1988). After centering the predictor variables (Dawson, 2014), six different regression analyses were run by entering each of the independent variables in two separate blocks and the interaction terms in the third block in each case (Cleary \& Kessler, 1982), testing if the moderator effect was significant. Table 4 shows that the interaction of organizational capabilities, marketing capabilities and technical capabilities with tacit knowledge, do not have any significant impact on product innovation. Therefore, $\mathrm{H}_{4}, \mathrm{H}_{6}, \mathrm{H}_{8}$ were not supported. However, the interaction of technical capabilities and tacit knowledge has a significant impact on firm performance. Therefore, $\mathrm{H}_{9}$ was supported, while $\mathrm{H}_{5}$ and $\mathrm{H}_{7}$ were rejected.

Table 4. Moderation effects

\begin{tabular}{|c|c|c|c|}
\hline \multicolumn{4}{|c|}{ Main effect of TK and moderation effect of OC on product innovation } \\
\hline Independent variable & Model 1 & Model 2 & Model 3 \\
\hline $\begin{array}{l}\text { TK } \\
\text { OC } \\
\text { TK x OC } \\
\text { Adjusted R square } \\
\text { F } \\
d f \text { (regression and residual) }\end{array}$ & $\begin{array}{c}0.651^{* * *} \\
\\
0.419 \\
10.785^{* * *} \\
151\end{array}$ & $\begin{array}{l}0.348^{* * *} \\
0.409^{* * *} \\
0.493 \\
74.850^{* * *} \\
150\end{array}$ & $\begin{array}{c}0.357^{* * *} \\
0.396^{* * *} \\
-0.056(0.343) \\
0.493 \\
50.171^{* * *} \\
149\end{array}$ \\
\hline \multicolumn{4}{|c|}{ Main effect of TK and moderation effect of MC on product innovation } \\
\hline $\begin{array}{l}\text { TK } \\
\text { MC } \\
\text { TK } x \text { MC } \\
\text { Adjusted R square } \\
\text { F } \\
d f \text { (regression and residual) }\end{array}$ & 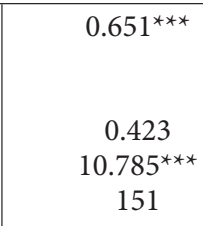 & $\begin{array}{l}0.447^{* * *} \\
0.303^{* * *} \\
0.473 \\
67.376^{* * *} \\
150\end{array}$ & $\begin{array}{c}0.438^{* * *} \\
0.316^{* * *} \\
-0.050(0.413) \\
0.476 \\
45.043^{* * *} \\
149\end{array}$ \\
\hline \multicolumn{4}{|c|}{ Main effect of TK and moderation effect of TC on product innovation } \\
\hline $\begin{array}{l}\text { TK } \\
\text { TC } \\
\text { TK x TC } \\
\text { Adjusted R square } \\
\text { F } \\
d f \text { (regression and residual) }\end{array}$ & $\begin{array}{l}0.423 \\
110.785^{\star * *} \\
151\end{array}$ & $\begin{array}{l}0.557^{\star \star \star} \\
0.217^{\star \star} \\
0.462 \\
64.315^{\star \star \star} \\
150\end{array}$ & \begin{tabular}{|l|}
$0.550^{\star * *}$ \\
$0.231^{\star * \star}$ \\
$0.097(0.110)$ \\
0.471 \\
$44.188^{\star * \star}$ \\
149
\end{tabular} \\
\hline
\end{tabular}


End of Table 4

\begin{tabular}{|c|c|c|c|}
\hline \multicolumn{4}{|c|}{ Main effect of TK and moderation effect of OC on product innovation } \\
\hline Independent variable & Model 1 & Model 2 & Model 3 \\
\hline \multicolumn{4}{|c|}{ Main effect of TK and moderation effect of OC on firm performance } \\
\hline $\begin{array}{l}\text { TK } \\
\text { OC } \\
\text { TK x OC } \\
\text { Adjusted R square } \\
\text { F } \\
d f \text { (regression and residual) }\end{array}$ & $\begin{array}{c}0.664^{\star * *} \\
\\
0.441 \\
119.279^{\star * *} \\
151\end{array}$ & $\begin{array}{c}0.273^{\star *} \\
0.530^{\star * *} \\
0.569 \\
99.111^{\star * *} \\
150\end{array}$ & $\begin{array}{c}0.259^{\star *} \\
0.554^{\star * \star} \\
0.097(0.074) \\
0.578 \\
68.134^{\star * *} \\
149\end{array}$ \\
\hline \multicolumn{4}{|c|}{ Main effect of TK and moderation effect of MC on firm performance } \\
\hline $\begin{array}{l}\text { TK } \\
\text { MC } \\
\text { TK x MC } \\
\text { Adjusted R square } \\
\text { F } \\
d f \text { (regression and residual) }\end{array}$ & $\begin{array}{c}0.664^{* * *} \\
\\
0.441 \\
119.279^{\star * *} \\
151\end{array}$ & $\begin{array}{c}0.300^{\star * *} \\
0.541^{\star * *} \\
0.602 \\
113.211^{\star * *} \\
150\end{array}$ & $\begin{array}{c}0.309^{* * *} \\
0.529^{* * *} \\
0.048(0.361) \\
0.604 \\
75.673^{\star * *} \\
149\end{array}$ \\
\hline \multicolumn{4}{|c|}{ Main effect of TK and moderation effect of TC on firm performance } \\
\hline $\begin{array}{l}\text { TK } \\
\text { MC } \\
\text { TK x MC } \\
\text { Adjusted R square } \\
\text { F } \\
d f \text { (regression and residual) }\end{array}$ & $\begin{array}{c}0.441 \\
119.279^{\star * *} \\
151\end{array}$ & $\begin{array}{c}0.300^{\star * *} \\
0.541^{\star * *} \\
0.602 \\
113.211^{\star * \star} \\
150 \\
\end{array}$ & $\begin{array}{c}0.309^{\star \star \star} \\
0.529^{\star \star *} \\
0.048(0.361) \\
0.604 \\
75.673^{\star * \star} \\
149 \\
\end{array}$ \\
\hline $\begin{array}{l}\text { TK } \\
\text { TC } \\
\text { TK } \times \text { TC } \\
\text { Adjusted R square } \\
\text { F } \\
d f \text { (regression and residual) }\end{array}$ & $\begin{array}{c}0.441 \\
119.279^{\star \star *} \\
151\end{array}$ & $\begin{array}{c}0.499^{\star * *} \\
0.384^{\star * *} \\
0.562 \\
96.108^{\star * *} \\
150\end{array}$ & $\begin{array}{c}0.488^{\star * \star} \\
0.405^{\star * *} \\
0.148^{\star *}(0.006) \\
0.583 \\
69.490^{\star * \star} \\
149\end{array}$ \\
\hline
\end{tabular}

Note: Tacit knowledge (TK); Organizational capabilities (OC); Marketing capabilities (MC); Technical capabilities (TC). ${ }^{* * *} p<0.001$.

Thus, the association between tacit knowledge and firm performance differs in accordance with the level of technical capabilities; however, it is not clear how it exactly differs. The interaction term is a positive coefficient, so the positive impact of tacit knowledge on firm performance increases as technical capabilities increase, however the size and precise nature of this effect is not easy to perceive, by merely examining the coefficients. Hence, the effect was plotted to interpret it visually (Dawson, 2014) by categorizing technical capabilities into three levels, low, moderate and high, to predict the relationship between tacit knowledge and firm performance at these three levels, obtaining three different regression groups. Figure 2 shows that a high level of technical capabilities has a strong regression effect $\left(\mathrm{R}^{2}\right.$ Lineal $=0.547$ ) on tacit knowledge firm performance relationship (correlation value $=0.73$ ). $\mathrm{R}^{2}$ Lineal technical capabilities moderate $=0.272$ (correlation value $=0.52$ ), and $\mathrm{R}^{2}$ Lineal technical capabilities low $=0.164$ (correlation value $=0.40)$. Thus, it is demonstrated that 
the relationship between tacit knowledge and firm performance is always positive, but such positive effect is far more for organizations with higher levels of technical capabilities than for those with lower levels.

Figure 3 summarizes the results of the hypotheses tested.

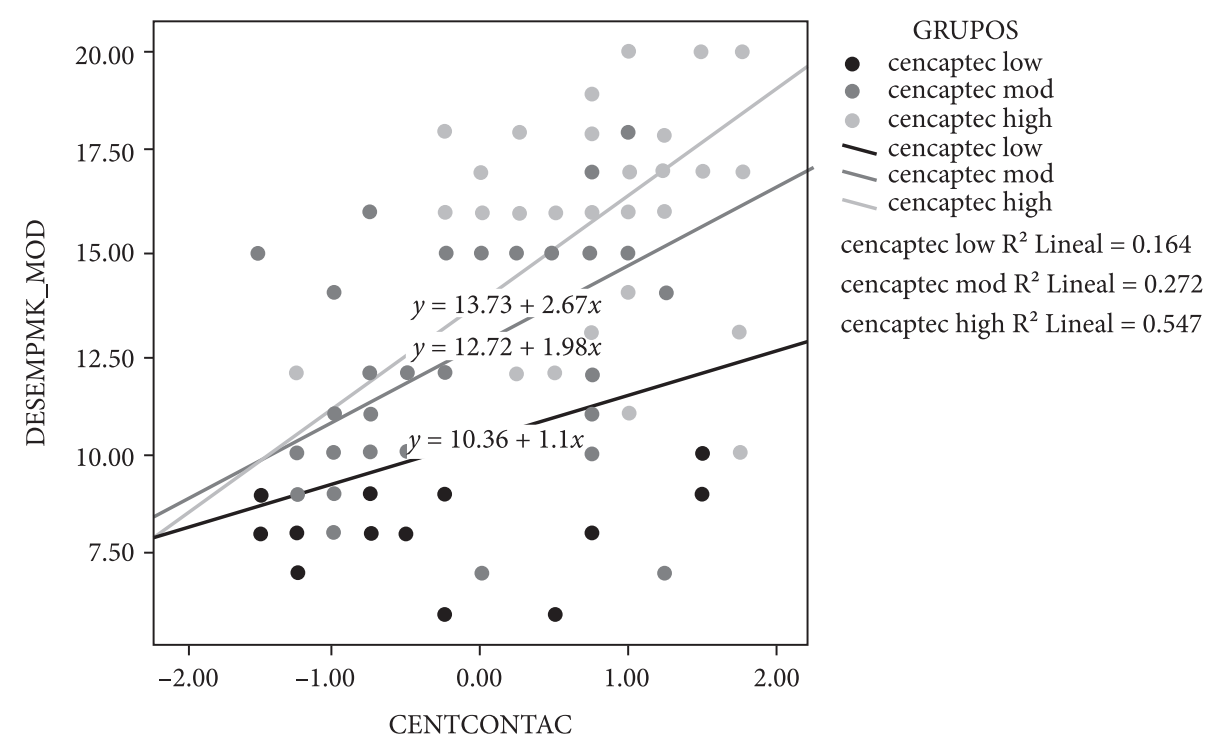

Figure 2. Graph of regression effects between tacit knowledge and firm performance depending on different levels of technical capabilities

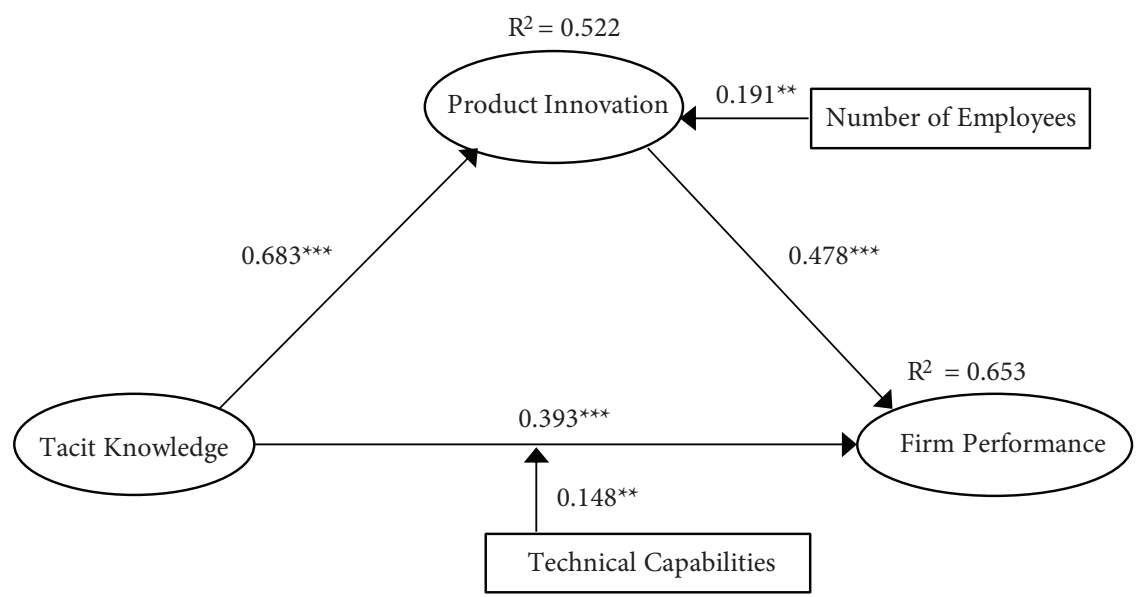

Note: ${ }^{*} p<0.05 ;{ }^{* *} p<0.01 ;{ }^{* *} p<0.001$.

Figure 3. Structural model 


\section{Discussion}

This study furthers the extant literature in knowledge management and dynamic capabilities by untangling the complex relationships linking tacit knowledge, product innovation, firm capabilities and firm performance. Tacit knowledge has strong positive relationship with product innovation $\left(\mathrm{H}_{1}\right)$. Results are broadly in line with Seidler-de Alwis and Hartmann (2008), Leal-Rodriguez et al. (2012), and Goffin and Koners (2011). Results also show that product innovation has a strong positive relationship with firm performance $\left(\mathrm{H}_{2}\right)$. In this case, results are broadly in line with Cucculelli and Ermini (2012) and Fernandes et al. (2013). Magnier-Watanabe and Benton (2017) did not find a direct impact of management innovation programs onto firm performance (being tacit and explicit knowledge fully mediators in this relationship), although the alignment of these programs with knowledge management initiatives enhanced performance. Results also show that tacit knowledge has a strong positive relationship with firm performance, providing support to $\mathrm{H}_{3}$. This is broadly in line with Chen and Mohamed (2010), Zeng and Tang (2014) and Harlow (2008), supporting the view that tacit knowledge plays a strategic role in providing competitive advantage resulting in organizational success (Grant, 1996a, 1996b). However, this result is not in line with the study of De Luca and Atuahene-Gima (2007), which did not show a significant direct relationship between tacit knowledge and firm performance. In the present study, the relationship between tacit knowledge and firm performance is partially mediated by product innovation, being the direct effect of tacit knowledge on firm performance smaller than the indirect effect between these two variables through product innovation. This result is very interesting as tacit knowledge being inimitable and being a source of competitive advantage for firms is being leveraged into superior firm performance. More important is the existence of the partially mediating effect; i.e., tacit knowledge's impact on firm performance is driven through product innovation.

There was no statistically significant moderating effect of organizational capabilities $\left(\mathrm{H}_{4}\right)$, marketing capabilities $\left(\mathrm{H}_{6}\right)$ and technical capabilities $\left(\mathrm{H}_{8}\right)$ on tacit knowledge product innovation relationship. This is not in line with recent studies of Leal-Rodriguez et al. (2012), Cheung, Myers, and Mentzer (2011), and Arnett and Wittmann (2014). Although not statistically significant, trying to understand the direction (sign logic) of the standardized beta coefficients (Table 4, Model 3) is interesting, since it is negative when the interaction variables pertaining to organizational capabilities and marketing capabilities are tested in the regression model, but not when interaction variable pertaining to technical capabilities is tested. This effectively means that with higher levels of marketing and organizational capabilities, the impact of tacit knowledge on the firm's product innovation capability is in fact diminishing. This is in line with Leonard-Barton's (1992) study that highlights the issue of core rigidities in new product innovation. Ju, Zhao, and Wang (2014), and Moorman and Miner (1997) also showed that certain external attributes can reduce the value of capabilities in terms of shared knowledge within firms.

Considering the moderation effects of capabilities on tacit knowledge firm performance relationship, it was surprising to see that only technical capabilities $\left(\mathrm{H}_{9}\right)$ showed a significant positive moderating effect, while organizational and marketing capabilities interactions with tacit knowledge were not significant $\left(\mathrm{H}_{5}\right.$ and $\left.\mathrm{H}_{7}\right)$. The results are not in line with several 
previous studies (Collis, 1994; Haas \& Hansen, 2007; Spanos \& Lioukas, 2001; Wu \& Lin, 2013). The insignificance of moderating effects of marketing capabilities is counter intuitive and is in contrast to recent studies of Morgan et al. (2009), and Krasnikov and Jayachandran (2008), who showed that marketing capabilities have a stronger impact on performance than $\mathrm{R} \& \mathrm{D}$ or operations capabilities, as it is more intensive in terms of tacit knowledge content. However, our results are in line with De Luca and Atuahene-Gima's (2007) study, which did not show significant moderation effects of tacit knowledge and organizational capabilities in explaining firm performance; or with the study of Nonaka et al. (1996), who considered capabilities like information technology important for turning an organization into a "knowledge creating company". The contradictory results justify the need for more research in this study area. Considering the theoretical contribution of Klepper (1996) in the area of industry life cycle and emergence of dominant design, this study concludes that the organizations are more focused on "failure prevention" strategies through improving efficiency performance in terms of technical capabilities directed towards cost and lead time reductions, rather than "success producing" strategies through enhancing market capabilities (Varadarajan, 1985) directed towards gaining market share (Krasnikov \& Jayachandran, 2008). Hence, the effect of technical capabilities is more vital in securing efficiency advantage than marketing and organizational capabilities.

\section{Managerial implications}

The vitality of tacit knowledge and its integration across the organization as a driver for both new product developments and superior firm performance has been reiterated by this study. Knowledge sharing through employee social integration, interdisciplinary knowledge sharing among scientists, engineers, technicians and commercial managers on a regular basis, or personalization to manage tacit knowledge are some of the options for the organizations. Results also show that, the antecedent for superior firm performance is product innovation, which in turn can be achieved through robust tacit knowledge management. Hence, knowledge management activities within organizations need to be aligned with the organization's strategic objectives, knowing that these ones could shift in dynamic environments and managers need to ensure that the scope of knowledge management activities is also dynamically aligned with such change.

This study results show that the impact of tacit knowledge on firm performance can be magnified by its ability to build technical capabilities in the form of efficient production departments, achieving economies of scale, or acquiring technical experience, technological capabilities and equipment. These can provide rich underpinnings for the managers in their resource allocation and the right mix of capabilities choices.

\section{Conclusions}

The fact that knowledge is a key organizational resource is already widely accepted in the industry, so top managers must look for the best way to articulate the knowledge vision for an organization. Since organizations are moving towards "intellectual and tacit knowledge" 
intensive environments, the role of managers to successfully integrate knowledge (mainly tacit) has become more demanding (Thall, 2005). The objective is to create networks of relationships capable of explaining how the individual and shared group knowledge can be harvested into competitive advantage. As any empirical study this one has some limitations. The limitation related to common method variance bias was previously mentioned. In addition, although the research setting and the variables considered in this study are important, integrating other variables like explicit knowledge could be interesting in future studies; especially, the interaction between tacit and explicit knowledge to generate new organizational capabilities considering their influence on firm performance. Research questions can also include, in what types of tacit knowledge should invest the firm, in what types of industry settings, and the type of capabilities that needs to be built, i.e., exploration or exploitation. Also, being organizational capabilities a broad theoretical construct (Krasnikov \& Jayachandran, 2008), future studies can analyse how different types of this variable impact on strategy and performance. Future studies can be replicated in other industries or sectors, as well as in emerging market contexts to highlight their idiosyncrasies as well as to generalize the results of this research.

\section{Funding}

This research did not receive specific grant from any funding agency in the public, commercial, or non-for-profit sectors.

\section{Author contributions}

MALC and SS conceived the article's idea. SGOM was responsible for data collection. MALC, SS, SGOM and PVR performed the data analysis and interpretation, and involved in drafting the article to its final stage.

\section{Disclosure statement}

Authors declare that there is no competing financial, professional, or personal interest from other parties.

\section{References}

Al-Hakim, L. A., \& Hassan, S. (2016). Core requirements of knowledge management implementation, innovation and organizational performance. Journal of Business Economics and Management, 17(1), 109-124. https://doi.org/10.3846/16111699.2012.720597

Arend, R. J. (2006). Test of the resource-based view: Do the empirics have any clothes? Strategic Organization, 4(4), 409-422. https://doi.org/10.1177/1476127006070309

Arnett, D. B., \& Wittmann, C. M. (2014). Improving marketing success: the role of tacit knowledge exchange between sales and marketing. Journal of Business Research, 67(3), 324-331. https://doi.org/10.1016/j.jbusres.2013.01.018 
Atuahene-Gima, K., Slater, S. F., \& Olson, E. M. (2005). The contingent value of responsive and proactive market orientations for new product program performance. Journal of Product Innovation Management, 22(6), 464-482. https://doi.org/10.1111/j.1540-5885.2005.00144.x

Bagozzi, R. P., \& Yi, Y. (1988). On the evaluation of structural equation models. Journal of the Academy of Marketing Science, 16(1), 74-94. https://doi.org/10.1177/009207038801600107

Balijepally, V., Mahapatra, R., Nerur, S., \& Price, K. H. (2009). Are two heads better than one for software development? The productivity paradox of pair programming. MIS Quarterly, 33(1), 91-118. https://doi.org/10.2307/20650280

Barley, W. C., Treem, J. W., \& Kuhn, T. (2018). Valuing multiple trajectories of knowledge: A critical review and agenda for knowledge management research. Academy of Management Annals, 12(1), 278-317. https://doi.org/10.5465/annals.2016.0041

Bivainis, J., \& Morkvènas, R. (2012). Integrated assessment of organization's knowledge potential. Journal of Business Economics and Management, 13(1), 81-94.

https://doi.org/10.3846/16111699.2011.620152

Brown, S., \& Duguid, P. (1998). Organizing knowledge. California Management Review, 40(3), 90-111. https://doi.org/10.2307/41165945

Cater, T., \& Cater, B. (2009). (In)tangible resources as antecedents of a company competitive advantage and performance. Journal for East European Management Studies, 14, 186-209. https://doi.org/10.5771/0949-6181-2009-2-186

Cavusgil, S. T., Calantone, R. J., \& Zhao, Y. (2003). Tacit knowledge transfer and firm innovation capability. Journal of Business and Industrial Marketing, 18(1), 6-21. https://doi.org/10.1108/08858620310458615

Chen, L., \& Mohamed, S. (2010). The strategic importance of tacit knowledge management activities in construction. Construction Innovation, 10(2), 138-163. https://doi.org/10.1108/14714171011037165

Cheung, M. S., Myers, M. B., \& Mentzer, J. (2011). The value of relational learning in global buyersupplier exchanges: A dyadic perspective and test of the pie-sharing premise. Strategic Management Journal, 32(10), 1061-1082. https://doi.org/10.1002/smj.926

Choi, B., \& Jong, A. (2010). Assessing the impact of knowledge management strategies announcements on the market value of firms. Information \& Management, 47(1), 42-52. https://doi.org/10.1016/j.im.2009.10.001

Choi, B., \& Lee, H. (2003). An empirical investigation of KM styles and their effect on corporate performance. Information \& Management, 40(5), 403-417. https://doi.org/10.1016/S0378-7206(02)00060-5

Cleary, P. D., \& Kessler, R. C. (1982). The estimation and interpretation of modified effects. Journal of Health and Social Behavior, 23, 159-169. https://doi.org/10.2307/2136512

Cohen, J., \& Cohen, P. (1983). Applied multiple regression/correlation analyses for the behavioral sciences. Hillsdale, NJ: Erlbaum.

Cohen, M., \& Levinthal, D. (1990). Absorptive capacity: A new perspective on learning and innovation. Administrative Science Quarterly, 35(1), 128-152. https://doi.org/10.2307/2393553

Collis, D. J. (1994). Research note: How valuable are organizational capabilities? Strategic Management Journal, 15, 143-152. https://doi.org/10.1002/smj.4250150910

Cucculelli, M., \& Ermini, B. (2012). New product introduction and product tenure: What effects on firm growth? Research Policy, 41(5), 808-821. https://doi.org/10.1016/j.respol.2012.02.001

Danneels, E. (2002). The dynamics of product innovation and firm competences. Strategic Management Journal, 23(12), 1095-1121. https://doi.org/10.1002/smj.275

Dawson, J. F. (2014). Moderation in management research: What, why, when and how. Journal of Business and Psychology, 29(1), 1-19. https://doi.org/10.1007/s10869-013-9308-7 
De Luca, L M., \& Atuahene-Gima, K. (2007). Market knowledge dimensions and cross-functional collaboration: Examining the different routes to product innovation performance. Journal of Marketing, 71(1), 95-112. https://doi.org/10.1509/jmkg.71.1.95

Fallatah, M. I. (2018). Does value matter? An examination of the impact of knowledge value on firm performance and the moderating role of knowledge breadth. Journal of Knowledge Management, 22(3), 678-395. https://doi.org/10.1108/JKM-08-2016-0355

Fernandes, C. I., Ferreira, J. J. M., \& Raposo, M. L. (2013). Drivers to firm innovation and their effects on performance: An international comparison. International Entrepreneurship Management Journal, 9(4), 557-580. https://doi.org/10.1007/s11365-013-0263-6

Flor, M., \& Oltra, A. J. (2005). The influence of firms' technological capabilities on export performance in supplier dominated industries: The case of ceramic tiles firms. R\&D Management, 35(3), 333-347. https://doi.org/10.1111/j.1467-9310.2005.00393.x

Fornell, C. F., \& Larcker, D. F. (1981). Evaluating structural equation models with unobservable variables and measurement error. Journal of Marketing Research, 18(1), 39-50. https://doi.org/10.2307/3151312

Gallego-Álvarez, I., Prado-Lorenzo, J. M., \& García-Sánchez, I. M. (2011). Corporate social responsibility and innovation: A resource-based theory. Management Decision, 49(10), 1709-1727. https://doi.org/10.1108/00251741111183843

Goffin, K., \& Koners, U. (2011). Tacit knowledge, lessons learnt, and new product development. Journal of Product Innovation Management, 28(2), 300-318. https://doi.org/10.1111/j.1540-5885.2010.00798.x

Grant, R. M. (1996a). Prospering in dynamically-competitive environments: Organizational capability as knowledge. Organization Science, 7(4), 375-387. https://doi.org/10.1287/orsc.7.4.375

Grant, R. M. (1996b). Toward a knowledge-based theory of the firm. Strategic Management Journal, 17(S2), 109-122. https://doi.org/10.1002/smj.4250171110

Haas, M. R., \& Hansen, M. T. (2007). Different knowledge, different benefits: Toward a productivity perspective on knowledge sharing in organizations. Strategic Management Journal, 28(11), 11331153. https://doi.org/10.1002/smj.631

Hair, J. F., Black, W. C., Babin, B. J., \& Anderson, R. (2010). Multivariate data analysis. New York: Prentice Hall.

Hair, J. F., Hult, G. T. M., Ringle, C. M., \& Sarstedt, M. (2014). A primer on partial least squares structural equation modeling (PLS-SEM). Los Angeles, CA: Sage.

Harlow, H. (2008). The effect of tacit knowledge on firm performance. Journal of Knowledge Management, 12(1), 148-163. https://doi.org/10.1108/13673270810852458

Harman, H. H. (1967). Modern factor analysis. Chicago: University of Chicago Press.

Heffner, M., \& Sharif, N. (2008). Knowledge fusion for technological innovation in organizations. Journal of Knowledge Management, 12(2), 79-93. https://doi.org/10.1108/13673270810859532

Heisig, P., Suraj, O. A., Kianto, A., Kemboi, C., Pérez-Arrau, G., \& Fathi-Easa, N. (2016). Knowledge management and business performance: Global experts' views on future research needs. Journal of Knowledge Management, 20(6), 1169-1198. https://doi.org/10.1108/JKM-12-2015-0521

Howells, J. (1996). Tacit knowledge, innovation and technology transfer. Technology Analysis \& Strategic Management, 8(2), 91-106. https://doi.org/10.1080/09537329608524237

Iyer, D. N., Sharp, B. M., \& Brush, T. H. (2017). Knowledge creation and innovation performance: An exploration of competing perspectives on organizational systems. Universal Journal of Management, 5(6), 261-270. https://doi.org/10.13189/ujm.2017.050601

Jayaram, J., Oke, A., \& Prajogo, D. (2014). The antecedents and consequences of product and process innovation strategy implementation in Australian manufacturing firms. International Journal of Production Research, 52(15), 4424-4439. https://doi.org/10.1080/00207543.2013.849363 
Ju, M., Zhao, H., \& Wang, T. (2014). The boundary conditions of export relational governance: A "strategy tripod" perspective. Journal of International Marketing, 22(2), 89-106. https://doi.org/10.1509/jim.13.01144

Kabir, N., \& Carayannis, N. (2013). Big data, tacit knowledge and organizational competitiveness. Journal of Intelligence Studies in Business, 2(3), 54-62.

Klepper, S. (1996). Entry, exit, growth and innovation over the product life cycle. The American Economic Review, 86(3), 562-583.

Kogut, B., \& Zander, U. (1992). Knowledge of the firm, combinative capabilities, and the replication of technology. Organization Science, 3(3), 383-397. https://doi.org/10.1287/orsc.3.3.383

Korsgaard, M. A., \& Roberson, L. (1995). Procedural justice in performance evaluation: The role of instrumental and non-instrumental voice in performance appraisal discussions. Journal of Management, 21(4), 657-669. https://doi.org/10.1177/014920639502100404

Krasnikov, A., \& Jayachandran, S. (2008). The relative impact of marketing, research-and-development, and operations capabilities on firm performance. Journal of Marketing, 72(4), 1-11. https://doi.org/10.1509/jmkg.72.4.1

Leal-Rodríguez, A., Leal-Millán, A., Roldán-Salgueiro, J. L., \& Ortega-Gutiérrez, J. (2012). Knowledge management strategy, relational learning and the effectiveness of innovation outcomes: A study in Spanish hospitals. In $13^{\text {th }}$ European Conference on Knowledge Management. Cartagena, Spain.

Leite, E. (2004). Gestão do conhecimento nas empresas brasileiras: Relações entre estratégia empresarial, gestão de competências e de resultado e impactos no desempenho do negócio [Knowledge management in Brazilian companies: Relationship between business strategy, management skills and results and impacts on business performance] (Ms Thesis). Pontificia Universidade Católica do Rio de Janeiro, Rio de Janeiro, Brasil.

Lentz, R., \& Mortensen, D. T. (2005). Productivity growth and worker reallocation. International Economic Review, 46(3), 731-751. https://doi.org/10.1111/j.1468-2354.2005.00344.x

Leonard, D., \& Sensiper, S. (1998). The role of tacit knowledge in group innovation. California Management Review, 40(3), 112-125. https://doi.org/10.2307/41165946

Leonard-Barton, D. (1992). Core capabilities and core rigidities: A paradox in managing new product development. Strategic Management Journal, 13, 111-125. https://doi.org/10.1002/smj.4250131009

Li, T., \& Calantone, R. J. (1998). The impact of market-knowledge competence on new product advantage: Conceptualization and empirical examination. Journal of Marketing, 62(4), 13-29. https://doi.org/10.2307/1252284

Lubit, R. (2001). The keys to sustainable competitive advantage: Tacit knowledge and knowledge management. Organizational Dynamics, 29(3), 164-78. https://doi.org/10.1016/S0090-2616(01)00026-2

Macher, J. T., \& Boerner, C. S. (2006). Experience and scale and scope economies: Trade-offs and performance in development. Strategic Management Journal, 27(9), 845-865. https://doi.org/10.1002/smj.540

Madhavan, R., \& Grover, R. (1998). From embedded to embodied knowledge: New product development as knowledge management. Journal of Marketing, 62(4), 1-12. https://doi.org/10.2307/1252283

Magnier-Watanabe, R., \& Benton, C. (2017). Management innovation and firm performance: The mediating effects of tacit and explicit knowledge. Knowledge Management Research \& Practice, 15(3), 325-335. https://doi.org/10.1057/s41275-017-0058-6

Moorman, C., \& Miner, A. S. (1997). The impact of organizational memory on new product performance and creativity. Journal of Marketing Research, 34(1), 91-106. https://doi.org/10.2307/3152067

Morgan, N. A., Vorhies, D. W., \& Mason, C. H. (2009). Market orientation, marketing capabilities, and firm performance. Strategic Management Journal, 30(8), 909-920. https://doi.org/10.1002/smj.764

Nonaka, I. (1994). A dynamic theory of organizational knowledge creation. Organization Science, 5(1), 14-37. https://doi.org/10.1287/orsc.5.1.14 
Nonaka, I., \& Takeuchi, H. (1995). The knowledge creating company. NY: Oxford University Press.

Nonaka, I., Umemoto, K., \& Senoo, D. (1996). From information processing to knowledge creation: A paradigm shift in business management. Technology in Society, 18(2), 203-218. https://doi.org/10.1016/0160-791X(96)00001-2

Paladino, A. E., Hargiss, K. M., \& Howard, C. (2016). The power of unstructured data: A study of the impact of tacit knowledge on business performance. International Journal of Strategic Information Technology and Applications, 7(4), 64-93. https://doi.org/10.4018/IJSITA.2016100102

Pertusa-Ortega, E. M., Molina-Azorín, J. F., \& Claver-Cortés, E. (2009). Competitive strategies and firm performance: A comparative analysis of pure, hybrid and "stuck-in-the-middle" strategies in Spanish firms. British Journal of Management, 20(4), 508-523. https://doi.org/10.1111/j.1467-8551.2008.00597.x

Pittiglio, R., \& Reganati, F. (2015). Multinational enterprises, technological intensity and firm survival. Evidence from Italian manufacturing and services firms. Atlantic Economic Journal, 43(1), 87-106. https://doi.org/10.1007/s11293-014-9441-3

Podsakoff, P. M., MacKenzie, S. B., Lee, J-Y., \& Podsakoff, N. P. (2003). Common method biases in behavioral research: A critical review of the literature and recommended remedies. Journal of Applied Psychology, 88(5), 879-903. https://doi.org/10.1037/0021-9010.88.5.879

Polanyi, M. (1962). Personal knowledge: Towards a post critical philosophy. London: Routledge.

Regner, P., \& Zander, U. (2011). Knowledge and strategy creation in multinational companies: SocialIdentity frames and temporary tension in knowledge combination. Management International Review, 51(6), 821-850. https://doi.org/10.1007/s11575-011-0110-3

Rivard, S., Raymond, L., \& Verreault, D. (2005). Resource based view and competitive strategy: An integrated model of the contribution of information technology to firm performance. Journal of Strategic Information Systems, 15, 29-50. https://doi.org/10.1016/j.jsis.2005.06.003

Ruvio, A. A., Shoham, A., Vigoda-Gadot, E., \& Schwabsky, N. (2014). Organizational innovativeness: Construct development and cross-cultural validation. Journal of Product Innovation Management, 31(5), 1004-1022. https://doi.org/10.1111/jpim.12141

Seidler-de Alwis, R., \& Hartmann, E. (2008). The use of tacit knowledge within innovative companies: Knowledge management in innovative enterprises. Journal of Knowledge Management, 12(1), 133147. https://doi.org/10.1108/13673270810852449

Shi, J., Chen, Z., \& Zhou, L. (2011). Testing differential mediation effects of sub-dimensions of political skills in linking proactive personality to employee performance. Journal of Business Psychology, 26(3), 359-369. https://doi.org/10.1007/s10869-010-9195-0

Sobel, M. E. (1982). Asymptotic intervals for indirect effects in structural equations models. In S. Leinhart (Ed.), Sociological methodology (Chapter 7). San Francisco: Jossey-Bass. https://doi.org/10.2307/270723

Song, M., Im, S., Bij, H. V., \& Song, L. Z. (2011). Does strategic planning enhance or impede innovation and firm performance? Journal of Product Innovation Management, 28(4), 503-520. https://doi.org/10.1111/j.1540-5885.2011.00822.x

Spanos, Y. E., \& Lioukas, S. (2001). An examination into the causal logic of rent generation: Contrasting Porter's competitive strategic framework and the resource-based view perspective. Strategic Management Journal, 22(10), 907-934. https://doi.org/10.1002/smj.174

Su, Z., Peng, J., Shen, H., \& Xiao, T. (2013). Technological capability, marketing capability, and firm performance in turbulent conditions. Management and Organization Review, 9(1), 115-137. https://doi.org/10.1111/j.1740-8784.2011.00280.x

Teece, D. J. (2007). Explicating dynamic capabilities: The nature and microfoundations of (sustainable) enterprise performance. Strategic Management Journal, 28(13), 1319-1350.

https://doi.org/10.1002/smj.640 
Teece, D. J., Pisano, G., \& Shuen, A. (1997). Dynamic capabilities and strategic management. Strategic Management Journal, 18(7), 509-533. https://doi.org/10.1002/(SICI)1097-0266(199708)18:7<509::AID-SMJ882>3.0.CO;2-Z

Terziovski, M., Sohal, A., \& Howell, A. (2002). Best practice in product innovation at Varian Australia. Technovation, 22(9), 561-569. https://doi.org/10.1016/S0166-4972(01)00060-8

Thall, J. B. (2005). The role of the manager in the conversion of tacit to explicit knowledge (Ms Thesis). George Washington University, Washington, USA.

Tippmann, E., Sharkey, P., \& Mangematin, V. (2014). Stimulating knowledge search routines and architecture competences: The role of organizational context and middle management. Long Range Planning, 47(4), 206-223. https://doi.org/10.1016/j.lrp.2013.11.001

Varadarajan, P. R. (1985). A two-factor classification of competitive strategy variables. Strategic Management Journal, 6(4), 357-75. https://doi.org/10.1002/smj.4250060405

Vorhies, D. W., \& Morgan, N. A. (2005). Benchmarking marketing capabilities for sustainable competitive advantage. Journal of Marketing, 69(1), 80-94. https://doi.org/10.1509/jmkg.69.1.80.55505

Wadho, W., \& Chaudhry, A. (2018). Innovation and firma performance in developing countries: The case of Pakistani textile and apparel manufacturers. Research Policy, 47(7), 1283-1294. https://doi.org/10.1016/j.respol.2018.04.007

Wang, T., \& Chen, Y. (2018). Capability stretching in product innovation. Journal of Management, 44(2), 784-810. https://doi.org/10.1177/0149206315594847

Wang, Z., \& Wang, N. (2012). Knowledge sharing, innovation and firm performance. Expert Systems with Applications, 39(10), 8899-8908. https://doi.org/10.1016/j.eswa.2012.02.017

Wilden, R., Gudergan, S. P., Nielsen, B. B., \& Lings, I. (2013). Dynamic capabilities and performance: Strategy, structure and environment. Long Range Planning, 46(1), 72-96. https://doi.org/10.1016/j.lrp.2012.12.001

Wu, L., \& Lin, J. (2013). Knowledge sharing and knowledge effectiveness: Learning orientation and coproduction in the contingency model of tacit knowledge. Journal of Business \& Industrial Marketing, 28(8), 672-686. https://doi.org/10.1108/JBIM-04-2011-0050

Zeng, L., \& Tang, X. (2014). Analysis of tacit knowledge and its dominant path. Canadian Social Science, 10(2), 50-55. https://doi.org/10.3968/4408 